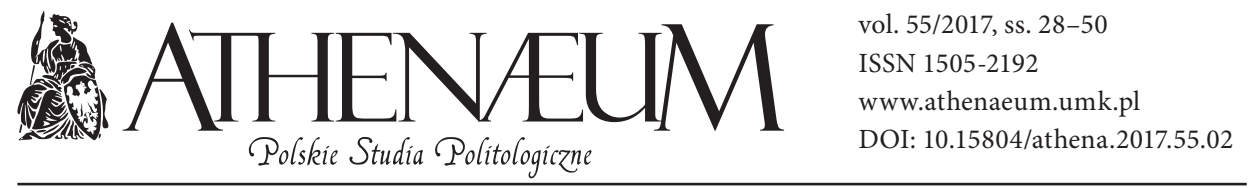

\title{
MIĘDZYNARODOWA SOCJOLOGIA HISTORYCZNA A STUDIA NAD BLISKIM WSCHODEM*
}

\author{
INTERNATIONAL HISTORICAL SOCIOLOGY AND THE MIDDLE \\ EASTERN STUDIES
}

Artur Malantowicz**

\begin{abstract}
ABSTRAKT
Klasyczne teorie stosunków międzynarodowych cechuje redukcjonizm $\mathrm{w}$ procesie wyjaśniania relacji między środowiskiem wewnętrznym państwa a jego otoczeniem międzynarodowym. Jest to szczególnie zauważalne, gdy teorie te aplikowane są do wyjaśniania rzeczywistości pozaeuropejskiej. W odpowiedzi na powyższe wątpliwości teoretyczne artykuł podejmuje próbę rekonstrukcji genezy, podstawowych założeń teoretycznych oraz kierunków badań w międzynarodowej socjologii historycznej. W dalszej kolejności autor prezentuje możliwe kierunki jej aplikacji do badania procesów i zjawisk zachodzących w obrębie tzw. globalnego Południa, na przykładzie regionu bliskowschodniego. Artykuł konkluduje stwierdzeniem, że koncept analityczny socjologii historycznej, ukazujący stosunki międzynarodowe jako trójkąt wzajemnie powiązanych i zanurzonych w kontekście historycznym elementów - państwa, społeczeństwa i wymiaru międzynarodowego - jest odpowiedzią na potrzebę wzmocnienia powiązań dyscypliny
\end{abstract}

The classical theories of international relations are reductionist in explaining the symbiosis between the domestic socio-political scene of the state and its international environment. It is particularly visible when these theories are applied to explain the realities of non-European states. The paper traces back the genesis, reconstructs main theoretical assumptions and indicates principal research fields within the literature of international historical sociology, in order to address the abovementioned shortcomings. Accordingly, it presents possible applicability of the theory to study processes and phenomena taking place in the Global South, as exemplified by the scholarship on the Middle East. The article concludes that the analytical concept of historical sociology, depicting international relations as a triangle of interconnected, interdependent and immersed in historical context elements - the state, the society, and the international realm - is an answer to the growing need to strengthen bonds between international relations and other disciplines.

* Projekt został sfinansowany ze środków Narodowego Centrum Nauki przyznanych na podstawie decyzji numer DEC-2013/11/N/HS5/04210.

** Uniwersytet Warszawski, Wydział Nauk Politycznych i Studiów Międzynarodowych. 
stosunków międzynarodowych $\mathrm{z}$ innymi dziedzinami nauki.

Słowa kluczowe: międzynarodowa socjologia historyczna, socjologia światowa, teoria stosunków międzynarodowych, Bliski Wschód
Keywords: international historical sociology, world sociology, theory of international relations, Middle East

Klasyczne teorie stosunków międzynarodowych nie wyjaśniają w stopniu niepozostawiającym wątpliwości relacji między środowiskiem wewnętrznym państwa a jego otoczeniem międzynarodowym. Zauważył to już znany amerykański politolog Robert Putnam (1993, s. 431), który stwierdził, że „polityka wewnętrzna oraz stosunki międzynarodowe są w jakiś sposób powiązane, ale nasze teorie jeszcze nie rozwikłały tego zagadkowego związku”. Ponadto podejścia te są często krytykowane jako nieadekwatne do badania rzeczywistości tzw. globalnego Południa ze względu na swój europocentryzm, rozdzielenie wyjaśniania geopolitycznego i socjologicznego czy przekonanie o jednoliniowości rozwoju (Allinson, 2015; Chatterjee, 2012).

Odpowiedzią na powyższe wątpliwości teoretyczne jest, zdaniem autora, koncepcja międzynarodowej socjologii historycznej (MSH), która dostrzega zarówno powiązania między polityką a procesami społecznymi, jak i między środowiskami wewnętrznym a zewnętrznym. W dużej mierze jest to podejście, dzięki któremu można badać procesy zmian poprzez uwzględnianie wielości aktorów oraz dostrzeganie relacji na linii struktura-agencja; podejście, które postrzega stosunki międzynarodowe jako trójkąt współzależnych i wzajemnie na siebie wpływających elementów - państwa, społeczeństwa i środowiska międzynarodowego - badanych w kontekście historycznym. Nie jest to jednak teoria stosunków międzynarodowych per se, a raczej zespół różnych perspektyw stanowiących podejście „historycystyczne” (historicist) do badania problematyki międzynarodowej (Linklater, 2013; Gałganek, 2012)ํ․ Mimo iż socjologia historyczna posiada znaczny potencjał analityczny, jest to podejście teoretyczne, które w Polsce pozostaje mało znane, i z całą pewnością wymagające szczegółowych

1 Gałganek (2012) używa terminu „historystyczny” jako tłumaczenie dla historicist. Autor zdecydował o użyciu terminu „historycystyczny” jako bardziej adekwatnego dla przymiotnika pochodzącego od terminu „historycyzm”, czyli poglądu postulującego poznawanie rzeczywistości w sposób historyczny. 
badań ${ }^{2}$ Niniejszy artykuł ma na celu przedstawienie podstawowych założeń i obszarów badawczych socjologii historycznej per se oraz jej odpowiednika w nauce o stosunkach międzynarodowych - międzynarodowej socjologii historycznej $^{3}$.W dalszej kolejności autor analizuje możliwości aplikacji omawianej teorii w badaniach nad kontekstami pozaeuropejskimi na przykładzie regionu bliskowschodniego.

\section{MIĘDZYNARODOWA SOCJOLOGIA HISTORYCZNA - GENEZA}

Socjologia historyczna w swojej współczesnej formie wykształciła się na przełomie lat sześćdziesiątych i siedemdziesiątych XX wieku w szkole anglosaskiej, a jej twórcy wywodzili się z różnych nurtów myśli socjologicznej. Przykładowo, Shmuel N. Eisenstadt reprezentował tradycję funkcjonalną, Perry Anderson, Theda Skocpol, Edward P. Thompson, Barrington Moore Jr. oraz Immanuel Wallerstein inspirowali się neomarksizmem, a Charles Tilly i Reinhard Bendix czerpali z socjologii Émile’a Durkheima i Maxa Webera (Kolasa-Nowak, 2001; zob. też: Skocpol, 1984; Smith, 1991).

W uproszczeniu socjologia historyczna jest badaniem przeszłości w celu wyjaśnienia, jak społeczeństwa funkcjonują i ulegają przemianom; badaniem, które w sposób interdyscyplinarny analizuje wzajemne powiązania między przeszłością a teraźniejszością oraz wydarzeniami a procesami (Smith, 1991). Stąd też wiele prac z tego nurtu porusza problem genezy współczesnego świata, m.in.: wykształcenia się i upowszechnienia gospodarki rynkowej, związków między kapitalizmem a zmianami organizacji politycznej, procesów państwotwórczych, ruchów społecznych czy zjawiska rewolucji. Interdyscyplinarność socjologii historycznej, tak w obszarze przedmiotu badań, jak i stosowanych metod badawczych, nie uniemożliwia jednak wskazania cech wspólnych wszystkich prac tego nurtu. Jak zaznacza Kolasa-Nowak (2001, s. 14), najważniejszą z nich

2 Nowatorskie badania w tym zakresie prowadzi Andrzej Gałganek z Uniwersytetu im. Adama Mickiewicza w Poznaniu, koncentrując się na neomarksistowskiej gałęzi socjologii historycznej, a w szczególności na abstrakcji nierównego i połączonego rozwoju wyprowadzanej z twórczości Lwa Trockiego. Zob. Gałganek (2007, 2009, 2010, 2013a, 2013b). Znacznie większa liczba autorów pisze na temat stricte socjologicznego ujęcia stosunków międzynarodowych, m.in.: Wiatr (1969), Paleczny (2001), Maj (2013).

3 W literaturze przedmiotu pojawiają się także nazwy: socjologia historyczna w stosunkach międzynarodowych oraz socjologia światowa. 
jest „ujmowanie rzeczywistości społecznej jako procesu i podkreślanie roli momentu historycznego, tempa i rytmu przekształceń", które spowodowane są różnokierunkowymi procesami o charakterze kumulatywnym, których zaś sprawcami są ludzie ograniczani przez struktury (zob. też: Kolasa-Nowak, 1996). Człowiek więc jest twórcą rzeczywistości społecznej, która, oczyma pierwszych socjologów historycznych, kształtuje się jedynie w ramach państw (Czaputowicz, 2008).

Sfera systemu międzynarodowego oraz relacji między państwami i społeczeństwami pojawiła się w analizach socjologii historycznej dopiero w 1979 roku, gdy wydana została książka Thedy Skocpol Państwa i rewolucje społeczne. Autorka postulowała w niej odejście od percepcji państwa, jako systemu zamkniętego, zwracając uwagę na fakt, że zmiany społeczne mogą zachodzić nie tylko pod wpływem czynników wewnętrznych (np. walki klas i presji gospodarczej), ale również w efekcie nacisków ze strony środowiska międzynarodowego (politycznych, militarnych, ekonomicznych etc.) - każde państwo czy społeczeństwo posiada swoje otoczenie, od którego rozwoju jest uzależnione (Skocpol, 1979; zob. też: Czaputowicz, 2008). Co więcej, od początku „stosunki międzynarodowe zazębiały się z istniejącymi strukturami politycznymi i klasowymi, aby promować i kształtować podobne zmiany w różnych państwach" (Skocpol, 1979, s. 20). Według Skocpol (1979) państwa nie można utożsamiać jedynie z interesami klas wewnętrznych (jak postulował marksizm) - jej zdaniem państwo posiada względem nich pewien zakres autonomii. Skocpol twierdziła ponadto, co spotkało się z późniejszą krytyką zwolenników socjologii historycznej, że państwa nie mają możliwości kształtowania środowiska międzynarodowego, stąd konieczne jest ich dostosowanie się do wymogów przetrwania obowiązujących w strukturze międzynarodowej; w przeciwnym razie państwa skazane są na porażkę w wojnie oraz następującą bezpośrednio po niej rewolucję społeczną (Hobson, 2000, 2002a). Krytycy zarzucali też Skocpol niekonsekwencję: na gruncie teoretycznym system międzynarodowy był przez nią rozumiany jako powiązanie aspektów politycznych i ekonomicznych, zanurzonych w kontekście historycznym; w empirii natomiast wszystko ograniczało się do wystąpienia warunków wojennych, które wyjaśniały zmianę społeczną. Słowami Hobdena (1998, s. 92), „Skocpol dostarczyła teorii systemu międzynarodowego, ale nie była w stanie jej zoperacjonalizować".

W ramach tzw. pierwszej fali socjologii historycznej w nauce o stosunkach międzynarodowych (SHNSM, Historical Sociology in International Relations) powstały także prace Anthony’ego Giddensa (1985), Raymonda Arona (1986), 
Michaela Manna (1986), Charlesa Tilly’ego (1990), bazujące przede wszystkim na neoweberowskiej myśli socjologicznej. Ich cechą wspólną było dążenie do powiązania rozwoju stosunków międzynarodowych z wewnętrznymi procesami społecznymi, co znajdowało się w opozycji do popularnych w owym czasie koncepcji neorealistycznych. Wymienione prace koncentrowały się na wewnętrznych źródłach władzy państwowej oraz interakcjach między płaszczyznami narodową i międzynarodową, podkreślały istotę niestabilności i nieciągłości systemu międzynarodowego oraz starały się przeciwstawić dominującej ontologii materialistycznej. Co ważne, brakowało im jednak spójnej i jednoznacznej definicji systemu międzynarodowego (Hobson, Lawson, Rosenberg, 2010). Równolegle miały miejsce przypadki zastosowania socjologii historycznej do innych nurtów teoretycznych, np. konstruktywizmu (John Ruggie), marksizmu (Robert Cox) czy poststrukturalizmu (Richard Ashley). Jak zauważa Hobson (2002a), mimo iż wszyscy wymienieni powyżej badacze mieli istotny wkład w rozwój socjologii historycznej, to ich podejścia teoretyczne były obarczone założeniami zbliżonymi do neorealizmu (np. przyjęcie centralnej roli anarchii, reifikacja struktury międzynarodowej etc.). W odpowiedzi na te właśnie „niedociągnięcia” w nauce o stosunkach międzynarodowych wykształciła się tzw. druga fala socjologii historycznej.

W przeciwieństwie do pierwszej fali, której głównymi twórcami byli socjolodzy i historycy piszący o problematyce międzynarodowej, druga fala była zdominowana przez badaczy stosunków międzynarodowych sensu stricto. Ich prace opierały się na różnych nurtach teoretycznych (marksizm, neoweberyzm, konstruktywizm, szkoła angielska, postmodernizm etc.) oraz poruszały różnorodną tematykę: genezę i zróżnicowanie systemów międzynarodowych, porządek społeczny międzynarodowego systemu finansowego, międzynarodowy wymiar współczesności czy powiązania między światem zewnętrznym a relacjami na linii państwo-społeczeństwo w procesach radykalnej zmiany (Hobson, Lawson, Rosenberg, 2010; Lawson, 2007). Wszystkim jednak przyświecał zamiar stworzenia „nowego podejścia do polityki globalnej, które jest zdolne do studiowania zmiany oraz, w szczególności, do włączenia innych aktorów i badania współzależności między środowiskami wewnętrznym i międzynarodowym” (Hobden, 2002, s. 55), podejścia, które zakłada, że polityka nie jest bytem autonomicznym, a współczesne stosunki międzynarodowe są zakorzenione tak w przeszłości, jak i teraźniejszości (Gałganek, 2012). Niemniej jednak, jak zaznaczają Hobson, Lawson, Rosenberg (2010), w wyniku drugiej fali SHNSM stała się na tyle wewnętrznie zróżnicowana, że niezwykle trudno jest zidentyfikować jej odrębny wkład do 
dyscypliny stosunków międzynarodowych. Stąd postulują oni konceptualizację trzeciej fali międzynarodowej socjologii historycznej (International Historical Sociology), której najważniejszą korzyścią jest wprowadzenie interdyscyplinarnej agendy intelektualnej do nauki o stosunkach międzynarodowych oraz odrzucenie jej eurocentryzmu.

\section{ZAŁOŻENIA TEORETYCZNE I KIERUNKI BADAŃ}

Międzynarodowa socjologia historyczna w jej dominującym neoweberowskim ujęciu, zgodnie z sugestywną nazwą, znajduje się na pograniczu historii, socjologii i nauki o stosunkach międzynarodowych, co ma na celu poszerzenie zakresu analiz kompleksowych zjawisk i procesów, jakimi są m.in. kapitalizm, liberalizm, system światowy, suwerenność, nacjonalizm, imperializm i procesy państwotwórcze. Jak zauważył Halliday (2009), socjologia historyczna mogłaby się również okazać przydatna w analizie innych zagadnień, niezwykle istotnych np. w studiach nad Bliskim Wschodem, tj. problematyki konfliktów i ich uwarunkowań, roli ideologii i religii w stosunkach międzynarodowych, problemu ruchów transnarodowych, zmian wewnętrznych w poszczególnych państwach regionu czy też ich polityce zagranicznej. Ta ostatnia jest „pochodną nie tylko wewnątrzpaństwowych działań jednostek i procesów biurokratycznych, ale także interesów państwa i klas społecznych oraz sprzeczności między ich interesami" (Halliday, 2009, s. 42). W tym duchu Allinson (2015) prezentował jordańskie sojusze geopolityczne $\mathrm{z}$ lat pięćdziesiątych XX wieku, wskazując na związek ich zmienności z toczącą się wówczas walką o dominację między ludnością pasterską a ludnością miejską (burżuazją) w Jordanii. Z kolei „ideologia i normy mają zasadnicze znaczenie nie jako główna warstwa życia politycznego, ale raczej jako część procesu legitymizacji i wywierania przymusu" (Halliday, 2009, s. 43).

Halliday (2002) stwierdził ponadto, że termin „socjologia historyczna” implikuje zarówno historyzację państwa, jak i umiejscowienie jego historii w kontekście międzynarodowym. „Uhistorycznienie [...] wymaga usytuowania bezpośrednio badanej rzeczywistości w szerszym kontekście historycznej struktury, w którą się wpisuje i w której działa. Niepodobna zrozumieć szczegółu bez zrozumienia całości, do której on przynależy. Tylko w ten sposób można dokładnie ocenić, co się zmienia, jak się zmienia i dlaczego się zmienia" (Wallerstein, 2007, s. 99, za: Gałganek, 2009, s. 54). W taki sposób na przykład Tariq 
Tell (2013) prezentuje historyczne procesy społeczno-ekonomiczne, które doprowadziły do wytworzenia się odpornego i trwałego systemu monarchicznego w Jordanii (opartego na strukturalnej zależności ludności plemiennej od państwa w wymiarze społeczno-gospodarczym), w tle umieszczając sterowany przez Brytyjczyków proces państwotwórczy oraz proces konsolidacji władzy przez kolejnych Haszymidów.

Z historii wynika więc dogłębna analiza znaczenia wydarzeń, przypadków oraz lokalnych specyfik; socjologia wnosi do badań zrozumienie, jak relatywnie stałe układy relacji społecznych wpływają na powyższe procesy; stosunki międzynarodowe wreszcie uświadamiają centralną rolę środowiska międzynarodowego w kształtowaniu dynamiki tych procesów (Hobson, Lawson, Rosenberg, 2010). W konsekwencji socjolodzy historyczni analizują rzeczywistość międzynarodową na trzech płaszczyznach: historii, struktury porządku społecznego i międzynarodowości. Sprawia to, że agendą intelektualną międzynarodowej socjologii historycznej stają się trzy pytania: 1) jak stosunki międzynarodowe zmieniały się na przestrzeni dziejów w różnych miejscach? (historia); 2) w jaki sposób stosunki międzynarodowe są powiązane $\mathrm{z}$ podstawowymi zasadami konstrukcji ludzkiego świata? (struktura); 3) w jaki sposób interakcja wielu porządków społecznych wpływa na naszą percepcję struktury społecznej i procesów historycznych? (międzynarodowość). Aby móc udzielić odpowiedzi na te pytania, czynniki zewnętrzne (międzynarodowe) są zestawiane i porównywane z czynnikami wewnętrznymi. W efekcie podejmowana jest próba odnalezienia wzorów i schematów wyjaśniających procesy historyczne, takie jak kryzysy regionalne wywołujące wojny, rozwój kapitalizmu i imperializmu czy procesy państwotwórcze (Hobson, Lawson, Rosenberg, 2010).W szczególności te ostatnie znalazły się w obszarze zainteresowania autorów MSH piszących o państwach tzw. globalnego Południa.

Halliday (1994; zob. też: Teschke, 2011) stwierdził, że państwo jest układem instytucji przymusu i administracji, którego głównym zadaniem jest pobór podatków i mobilizacja wojskowa w celu geopolitycznego przetrwania oraz kontroli administracyjnej. Państwa rozwinęły się natomiast w historycznym kontekście światowym, tzn. w interakcji z innymi państwami, czy jednostkami politycznymi. Ponieważ wewnętrzne konstytuowanie się państw i społeczeństw jest mało odporne na wpływ zjawisk międzynarodowych, to właśnie one przyniosły kontekst i miały formatywny charakter względem państw. Co ważne, na co zwrócił uwagę sam Halliday, sytuacja ta odnosi się nie tylko do krajów tzw. globalnego Południa, ale również do państw europejskich. 
W sukurs Hallidayowi idzie inny badacz Bliskiego Wschodu: Hinnebusch (2010) konstatuje, że charakter reżimów bliskowschodnich jest ściśle związany z kontekstem historycznym oraz procesem państwotwórczym. Różne drogi formowania się państw w regionie są w rzeczywistości efektem tego, jak strategie twórców tych jednostek politycznych odnosiły się do trzech wyzwań: tworzenia narodu, rozwoju ekonomicznego oraz budowania władzy. Owe strategie zaś „były w znacznej mierze kształtowane przez ograniczenia środowiskowe oraz sposobności na poziomie międzynarodowym (zmiany w polaryzacji, pogłębiająca się globalizacja), na poziomie regionalnym (tożsamość, wojna, ropa naftowa) oraz na poziomie wewnętrznym (kultura polityczna oraz równowaga sił społecznych)" (Hinnebusch, 2010, s. 202). Wystarczająca zgodność między przyjętymi strategiami a środowiskiem gwarantowała stabilne efekty, czyli przetrwanie reżimów. Nieco odmienne podejście do analizy procesów państwotwórczych, oparte na abstrakcji nierównego i połączonego rozwoju, prezentuje Matin (2007) na przykładzie przednowoczesnego Iranu. Wskazuje on, jak proces budowania wzajemnych relacji, a następnie dominacji ludności koczowniczej nad osiadłą ludnością rolniczą doprowadził do wykształcenia się instytucji społecznych i politycznych, które do dziś towarzyszą patrymonialnej władzy centralnej w Iranie.

Międzynarodowa socjologia historyczna jest definiowana jako „podejście krytyczne, które odmawia traktowania teraźniejszości jako bytu autonomicznego i niezależnego od historii oraz które podkreśla jej zakorzenienie w specyficznej czasoprzestrzeni społecznej, a tym samym oferuje alternatywy dla ahistorycznych iluzji chronofetyszyzmu (chronofetishism) i tempocentryzmu (tempocentrism)" (Hobson, 2002b, s. 13), które są głównymi przejawami dominujących nurtów teorii stosunków międzynarodowych. Chronofetyszyzm opiera się na założeniu, że stan obecny jest autonomiczny, spontaniczny i samostanowiący, w związku z czym może on być wyjaśniany jedynie poprzez badanie teraźniejszości. Jego zastosowanie prowadzi z kolei do trzech iluzji: reifikacji, naturalizacji i niezmienności. Drugi z przejawów ahistorycyzmu - tempocentryzm - wprowadza iluzję izomorfizmu, która zakłada, że wszystkie systemy międzynarodowe są tożsame, niezależnie od czasu ich powstania (Hobson, 2002b). Socjologia historyczna niesie ze sobą konkretne postulaty, które mają na celu rozwianie tych iluzji (tabela 1), bowiem dla niej „przeszłość nie jest tak naprawdę miniona, ale nieustannie obecna i wpływająca na teraźniejszość [poprzez] całokształt praktyk i idei, które przenikają i nadają kierunek współczesnym decyzjom ludzkości. Teraźniejszość, innymi słowy, jest tym, co przeszłość - w formie odbieranej i interpretowanej przez teraźniejszość - stworzyła" (Bryant, 1994, s. 11). 
Tabela 1. Konceptualizacja dwóch dominujących typów ahistorycyzmu w teorii stosunków międzynarodowych

\begin{tabular}{|c|c|c|}
\hline $\begin{array}{c}\text { Typ } \\
\text { ahistorycyzmu }\end{array}$ & Powodowane iluzje & $\begin{array}{l}\text { Odpowiedź socjologii historycznej } \\
\text { (SH) }\end{array}$ \\
\hline \multirow{3}{*}{$\begin{array}{l}\text { Chronofety- } \\
\text { szyzm }\end{array}$} & $\begin{array}{l}\text { (1) Iluzja reifikacji, gdzie teraźniejszość } \\
\text { efektywnie odcina się od przeszłości, } \\
\text { tym samym przysłaniając jej historyczny } \\
\text { kontekst społeczny oraz sprawiając pozór } \\
\text { jej niezmiennego, autonomicznego, samo- } \\
\text { stanowiącego się i uprzedmiotowionego } \\
\text { charakteru; }\end{array}$ & $\begin{array}{l}\text { (1) SH prezentuje teraźniejszość jako } \\
\text { wytwór pewnej ciągłości, który jest } \\
\text { osadzony w kontekście historycznym, } \\
\text { tym samym ujawniając procesy powiązań } \\
\text { i zależności z dotychczasowymi praktyka- } \\
\text { mi społecznymi; }\end{array}$ \\
\hline & $\begin{array}{l}\text { (2) Iluzja naturalizacji, która stwierdza, } \\
\text { że teraźniejszość wykształciła się sponta- } \\
\text { nicznie, w nawiązaniu do „naturalnych” } \\
\text { ludzkich imperatywów, a z pominięciem } \\
\text { historycznych procesów władzy społecz- } \\
\text { nej, tożsamości i wykluczenia społecznego } \\
\text { oraz norm tworzących współczesność; }\end{array}$ & $\begin{array}{l}\text { (2) SH denaturalizuje teraźniejszość oraz } \\
\text { ujawnia, że nie powstała ona w wyniku } \\
\text { „naturalnych” ludzkich impulsów, } \\
\text { lecz raczej w efekcie procesów władzy, } \\
\text { tożsamości i wykluczenia społecznego } \\
\text { oraz norm; }\end{array}$ \\
\hline & $\begin{array}{l}\text { (3) Iluzja niezmienności, gdzie teraź- } \\
\text { niejszości przyznaje się charakter wieczny, } \\
\text { zakłada się jej naturalność i odporność na } \\
\text { zmiany strukturalne. }\end{array}$ & $\begin{array}{l}\text { (3) SH ujawnia, że teraźniejszość jest } \\
\text { tworzona przez procesy transformatywne } \\
\text { (morfogenetyczne), które nieustannie } \\
\text { zmieniają obecne instytucje i praktyki. }\end{array}$ \\
\hline Tempocentryzm & $\begin{array}{l}\text { (4) Iluzja izomorfizmu, w której } \\
\text { znaturalizowana i uprzedmiotowiona } \\
\text { teraźniejszość jest ekstrapolowana wstecz } \\
\text { w celu ukazania wszystkich historycznych } \\
\text { systemów jako izomorficznych; uniemoż- } \\
\text { liwia to dostrzeżenie unikatowych cech } \\
\text { stanu współczesnego. }\end{array}$ & $\begin{array}{l}\text { (4) SH poszukuje fundamentalnych różnic } \\
\text { między dawnymi a obecnymi systemami } \\
\text { i instytucjami międzynarodowymi w celu } \\
\text { ukazania unikatowych charakterystyk } \\
\text { stanu współczesnego. }\end{array}$ \\
\hline
\end{tabular}

Źródło: J. Hobson (2002), „What’s at stake in 'bringing historical sociology back into international relations'? Transcending 'chronofetishism' and 'tempocentrism' in international relations” (s. 7), W: S. Hobden, J. Hobson (red.), Historical Sociology of International Relations (s. 3-41), Cambridge: Cambridge University Press .

Przykładowo, Sandra Halperin (2005) wydarzenia lat pięćdziesiątych i sześćdziesiątych XX wieku na Bliskim Wschodzie uznaje za kluczowe z punktu widzenia trwałości reżimów autorytarnych w regionie. Jak argumentuje, w wyniku wspólnoty interesów regionalne elity rządzące (pragnące zmonopolizować dostęp do nowych zasobów i środków produkcji) oraz mocarstwa zachodnie (chcące zagwarantować bezpieczeństwo rozwoju kapitalizmu) podjęły działania zmierzające do usunięcia nie tylko komunistów i socjalistów, lecz także pozostałych 
ruchów wzywających do demokratyzacji czy reformy agrarnej, włączając w to liberałów, lewicę i centrum. Pod pretekstem zwalczania sowieckich wpływów $\mathrm{w}$ regionie elity zagarnęły kapitał i dobrobyt, tym samym utrwalając dotychczasowe struktury klasowe oraz utrudniając rozwój innych klas społecznych. Jedyną grupą, która otrzymała wówczas przyzwolenie na swoją działalność, była antydemokratyczna religijna prawica, gdyż stanowiła przeciwwagę dla radykalnej lewicy. Skutki tych wydarzeń w postaci słabości świeckiej opozycji wobec systemów autorytarnych w regionie są obserwowane do dziś.

Co więcej, międzynarodowa socjologia historyczna postuluje odejście od instrumentalnego traktowania historii, które wykorzystuje dowody empiryczne do potwierdzania założeń teoretycznych na rzecz rozwoju i adaptacji własnych kategorii analizy w oparciu o badanie materiału historycznego. Konsekwentnie, stając w opozycji do ahistorycyzmu, koncepcja ta podkreśla rolę zgłębiania genezy i rozwoju społecznych instytucji i praktyk oraz strukturalnej zmiany. Oferuje tym samym ideę kompleksowości, w przeciwieństwie do dominującego w sferze teorii stosunków międzynarodowych redukcjonizmu (Hobson, 2002a). Innymi słowy, socjologia historyczna proponuje zmiany epistemologiczne, które mają być odpowiedzią na redukcjonizm neorealizmu i marksizmu. Zdaniem zwolenników MSH właściwa teoria państwa, społeczeństwa i stosunków międzynarodowych powinna obejmować:

1. badanie historii i zmiany,

2. wieloprzyczynowość (wiele niezależnych źródeł władzy),

3. wielowymiarowość (postrzeganie przestrzeni jako zazębiającej się, bez jasnych granic między wieloma niezależnymi wymiarami),

4. częściową autonomię źródeł władzy i aktorów,

5. historycyzm - kompleksowość idei historii i zmiany,

6. (nierealistyczną) teorię autonomii i władzy państwa (Hobson, 1998;

Lapointe, Dufour, 2012; zob. też: Halperin, 1998).

Wieloprzyczynowość jest powszechnie akceptowana przez przedstawicieli socjologii historycznej jako metoda analizy rozwoju relacji na linii państwo-społeczeństwo; stosowali ją m.in. Theda Skocpol, Immanuel Wallerstein, Charles Tilly, John Hall czy Michael Mann. Ten ostatni stwierdził (Hobson, 2000), że najlepiej jest zrozumieć społeczeństwa, ich strukturę i historię przez pryzmat współzależności czterech rodzajów władzy społecznej - ideologicznej, ekonomicznej, militarnej i politycznej, którym odpowiadają rodzaje kontroli: ideologia i system przekonań, środki produkcji, siła militarna oraz państwo i jego instytucje polityczne. Jego zdaniem każdy z rodzajów władzy posiada swoją częściową 
autonomię, ale jednocześnie wszystkie cztery wzajemnie się kształtują i na siebie wpływają (rysunek 1). Zazwyczaj rozwój społeczny jest efektem równego oddziaływania wszystkich czynników, lecz okresowo jeden bądź kilka z nich może mieć charakter dominujący (Smith, 2002).

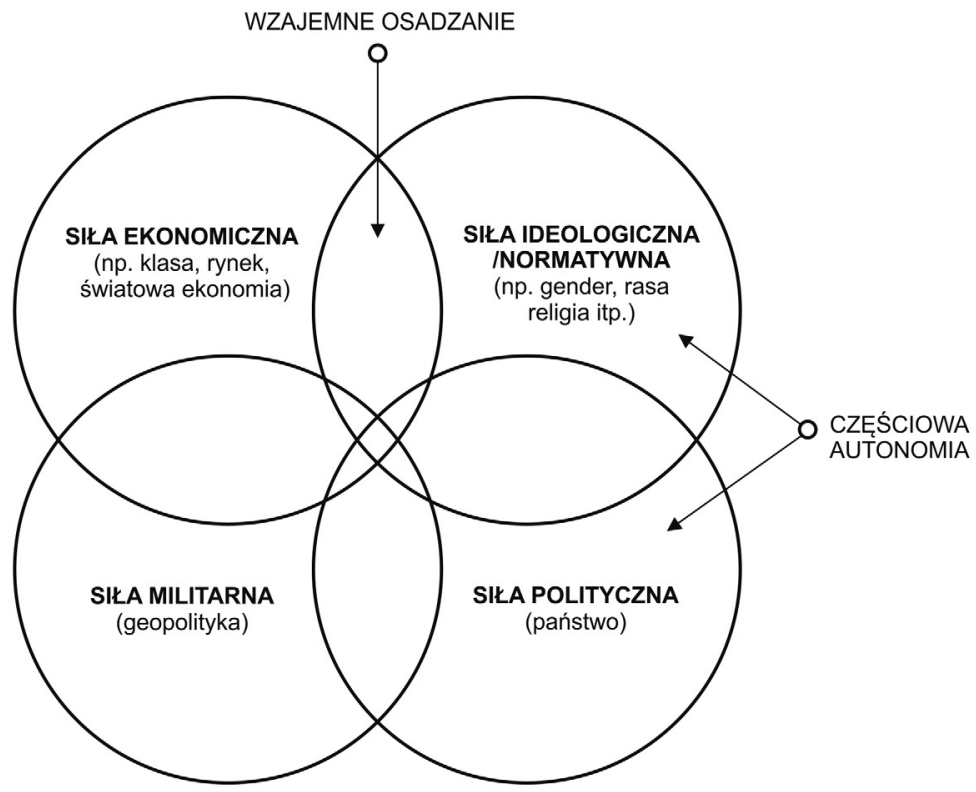

ŹRÓDŁA SIŁY SA CZEŚ́CIOWO AUTONOMICZNYMI ZMIENNYMI ZALEŻNYMI

Rysunek 1. Źródła siły państwa w modelu neoweberowskiej socjologii historycznej

Źródło: J. Hobson (2000). State and International Relations (s. 196), Cambridge: Cambridge University Press.

Ponadto socjologia historyczna przekonuje, że zrozumienie współczesnych stosunków społecznych wymaga wiedzy na temat krótko- i długoterminowych procesów i wydarzeń, które je poprzedzały. Takie założenie wiąże się z odrzuceniem powyżej opisanego chronofetyszyzmu oraz akceptacją „drogi zależności” (path dependency), która zasadza się na uznaniu obecnych warunków jako 
konsekwencji przeszłości (Mahoney, 2000) ${ }^{4}$. Co istotne, MSH jest daleka od stwierdzenia, że owa droga jest linearna bądź strukturalnie zdeterminowana. Wręcz przeciwnie, dominuje przekonanie, że jest ona historią konfliktu i zmagań między jednostkami, grupami, społecznościami politycznymi, narodami, religiami czy imperiami, które wzajemnie na siebie oddziaływały w obrębie szybko zmieniających się kontekstów konstruujących politykę światową (Lawson, 2007). Jak zauważa Gałganek (2012, s. 80), „rozwój społeczny jest nie tylko wielokierunkowy, ale także interaktywny i współzależny. Okoliczności te powodują, że wewnętrzne wzorce rozwoju mogą zostać przerwane przez zewnętrzne wydarzenia, zdeterminowane i przekształcone przez zewnętrzne presje, a nawet opóźnione lub przyspieszone przez rozwój innych społeczeństw. W świecie składającym się z więcej niż jednego społeczeństwa dzieje się to nieustannie”.

Międzynarodowa socjologia historyczna zakłada wielowymiarowość, współistnienie różnych poziomów przestrzennych - subnarodowego, narodowego, międzynarodowego i globalnego - wzajemnie na siebie wpływających i w sobie umocowanych. Innymi słowy, każdy z wymiarów przestrzennych nie może istnieć samodzielnie: społeczeństwo, państwo i społeczność międzynarodowa są ściśle ze sobą powiązane (Hobson, 2000). Nie jest zatem możliwe wyjaśnienie polityki indywidualnych aktorów (państw) bez odniesienia się do wielu czynników tak wewnętrznych, jak i międzynarodowych, historycznych i współczesnych. Konieczne jest połączenie eksplanacji socjologicznej, koncentrującej się na naturze społeczeństw, oraz eksplanacji geopolitycznej, opierającej się na warunkach generowanych przez ich (społeczeństw) współistnienie - oba poziomy są komplementarne w procesie wyjaśniania stosunków międzynarodowych (Gałganek, 2007; zob. też: Rosenberg, 2006). W odniesieniu do problematyki bliskowschodniej czyni to np. Hinnebusch (2014a, 2014b), podkreślając nielinearność zmian obserwowanych w trakcie tzw. arabskiej wiosny oraz ich zakorzenienie w działaniach i instytucjach społeczno-politycznych, które były konsekwentnie reprodukowane przez kolejne pokolenia, tym samym stając się produktem „drogi zależności”.

4 Koresponduje to z postulowanym przez Józefa Kukułkę na gruncie polskiej nauki o stosunkach międzynarodowych determinizmem historycznym, który uznaje istnienie obiektywnych oraz niezależnych od podmiotowych uczestników stosunków międzynarodowych prawidłowości funkcjonowania i rozwoju oddziaływań międzynarodowych. Zdaniem Kukułki jest to jedna z czterech ogólnometodologicznych zasad poznania właściwych dla nauki o stosunkach międzynarodowych. Zob. Kukułka, 1978, 2000. 
Środowisko międzynarodowe nie jest jedynie tłem dla funkcjonowania państw, lecz ma charakter dominujący; decyduje o kształtowaniu się państw i systemów politycznych. Państwa zaś działają jednocześnie na obu poziomach - wewnętrznym i zewnętrznym, starając się maksymalizować korzyści na jednej z płaszczyzn, aby umocnić swoją pozycję na drugiej. Innymi słowy, państwa konkurują ze sobą, mobilizując ku temu zasoby wewnętrzne oraz wykorzystują swoją rolę międzynarodową do konsolidacji pozycji na scenie krajowej. Przykładowo, państwa mogą zajmować terytoria, uczestniczyć w wojnach lub zawierać określone sojusze w celu pozyskania korzyści wewnętrznych, a jednocześnie mogą podejmować określone reformy (ekonomiczne, polityczne) oraz promować pewne zachowania społeczne z zamiarem osiągnięcia konkretnych celów na arenie międzynarodowej. Jak podkreśla Halliday (1994), konieczne jest jednak zbalansowanie obu tych obszarów aktywności państwa, jako że w przeciwnym razie może to doprowadzić do jego skonfliktowania bądź z innymi państwami, bądź z własnym społeczeństwem. Warto zauważyć, że socjologia historyczna podkreśla fakt posiadania przez państwo zarówno tzw. wewnętrznej władzy agencyjnej (domestic agential state power), jak i międzynarodowej władzy agencyjnej (international agential state power), co oznacza, że państwo ma zdolność do budowania swojej polityki i kształtowania wymiarów wewnętrznego i międzynarodowego niezależnie od ograniczeń strukturalnych oraz wpływu aktorów pozapaństwowych. Takie ujęcie umożliwia podjęcie analizy położenia społeczno-politycznego państwa oraz jego statusu jako aktora w stosunkach międzynarodowych ${ }^{5}$.

Konsekwentnie zwolennicy MSH stwierdzają, że środowisko międzynarodowe nie jest autonomiczne - po części jest ono kształtowane także przez czynniki wewnętrzne, np. klasy społeczne, wewnętrzne normy, tożsamości społeczne oraz społecznie uwarunkowane relacje na linii państwo-społeczeństwo. Przykładowo, Bromley (1994) poprzez analizę stosunków społecznych, mających, jego zdaniem, decydujący wpływ na procesy formowania się państw i ich rozwoju, próbuje wyjaśnić współczesne oblicze Bliskiego Wschodu. Ponadto sprzeciw budzi postrzeganie otoczenia międzynarodowego jako wewnętrznie niezróżnicowanego monolitu. Socjologia historyczna zaznacza, że obok elemen-

5 Pierwsza fala neoweberowskiej socjologii historycznej, podobnie jak neorealizm, reifikowała strukturę międzynarodową, tym samym negując istnienie międzynarodowej władzy agencyjnej państwa. Z kolei druga fala SHNSM w sposób jednoznaczny podkreśla, że państwa i społeczeństwa mają potencjał do kształtowania systemu międzynarodowego, podobnie jak wpływ na nie ma sam system międzynarodowy. Szerzej zob. Hobson, 2002a. 
tów politycznych, gospodarczych i militarnych występują również inne kategorie decydujące o jego kształcie, np. instytucje międzynarodowe oraz normy społeczne i moralne o globalnym charakterze. Środowisko międzynarodowe zaś, co wydaje się szczególnie istotne w kontekście krytyki chronofetyszyzmu, przyjmowało różny charakter w różnych momentach historii (Hobson, Hobden, 2002).

$\mathrm{W}$ tej postaci socjologia historyczna przyjmuje założenia zbliżone do konstruktywizmu - oba nurty koncentrują się na badaniu zmian społecznych w czasie, wzywają do podnoszenia świadomości o powiązaniach między agencją a strukturą czy też do stosowania wyjaśniania wieloprzyczynowego. Konstruktywizm jest przy tym bardziej redukcyjny, socjologia historyczna z kolei podejmuje bardziej szczegółowe analizy relacji państwo-społeczeństwo (Barnett, 2002). Z drugiej strony zwolennicy konstruktywizmu zarzucają podejściu międzynarodowej socjologii historycznej racjonalne wyjaśnianie ludzkiego zachowania, a tym samym nadmierną koncentrację na aspektach materialnych rzeczywistości oraz, mimo ich dostrzegania, niedocenianie ideologii, norm i wartości. Podkreślają też, podobnie jak podejście neoliberalne, konieczność analizy roli formalnych i nieformalnych organizacji międzynarodowych w kształtowaniu wewnętrznych struktur i instytucji państwowych czy kreowaniu społecznych tożsamości i interesów poszczególnych państw (Reus-Smit, 2002).

Socjologia historyczna dostrzega ponadto trend homogenizacji świata, upodabniania się instytucji politycznych pod wpływem nowoczesności oraz kontekstów regionalnych, co ma służyć umacnianiu międzynarodowej legitymizacji oraz stabilności. Po raz kolejny ukazuje to, w jakim stopniu ustalenia władzy wewnętrznej są uzależnione od czynników międzynarodowych oraz jak bardzo czynniki wewnętrzne wpływają na kształtowanie się polityki zagranicznej. Innymi słowy, „w nowoczesnych warunkach politycznych i społecznych państwa, elity, całe systemy polityczne zaczynają działać mniej więcej w podobny sposób..." (Halliday, 2009, s. 45; zob. też: Halliday, 1994). Nie inaczej jest w przypadku Bliskiego Wschodu. Kraje tego regionu prowadzą podobne polityki, łączy je zbliżona geneza ich powstania oraz uczestnictwo w tych samych konfliktach. Wynika to m.in. z wzajemnego naśladowania się elit, silnych powiązań finansowych i osobistych oraz wspólnej kultury i języka politycznego. Do badania tych procesów dobrze nadaje się międzynarodowa socjologia historyczna, która kładzie silny nacisk na kształtowanie się i przeobrażanie idei (Halliday, 2009).

Jednym z takich procesów, które wpisują się w trend homogenizacji porządku światowego, jest demokratyzacja. Już na początku lat dziewięćdziesiątych 
XX wieku zwrócono uwagę, że może ona odegrać kluczową rolę w analizie problematyki demokratyzacji. Smith (1991) stwierdził wówczas, że największą zasługą socjologii historycznej mogłoby być właśnie odkrycie oraz upowszechnianie wiedzy istotnej dla rozwoju demokracji. Doskonałym tego przejawem jest np. analiza zmiennych funkcji państwa oraz zmiennych definicji społeczeństwa obywatelskiego, na które MSH zwraca szczególną uwagę. Podobnie jest ze środowiskiem międzynarodowym, w którym omawiane podejście teoretyczne doszukuje się wzorów do naśladowania. Idąc dalej, socjologia historyczna stwierdza w oparciu o analizę struktury społecznej, że demokracja wymaga równowagi między władcą (państwem) a niezależnymi grupami społecznymi (społeczeństwem). W równowadze tej państwo nie jest ani w pełni autonomiczne, ani uzależnione od dominujących klas, dzięki czemu pozostawiona jest przestrzeń, w obrębie której może się wykształcić społeczeństwo obywatelskie. Konsekwentnie demokratyzacja wymaga zbudowania „demokratycznej koalicji”, składającej się z burżuazji, klasy średniej i klasy robotniczej; dopiero inkluzja dwóch ostatnich grup sprawia, że można mówić o procesie demokratyzacji, a nie liberalizacji politycznej (Hinnebusch, 2006).

Ponadto międzynarodowa socjologia historyczna uznaje, że demokratyzacja jest zależna od uprzednio obranej ścieżki, co oznacza, że „dziedzictwo przeszłości - kulturowe, polityczne i społeczne - warunkuje, kształtuje i ogranicza to, jak (oraz czy) demokratyzacja zachodzi oraz jak wygląda percepcja kluczowych aktorów na temat tego, co jest, a co nie jest możliwe" (Grugel, 2002, s. 10). Analizę tej problematyki na przykładzie Jordanii podejmuje Malantowicz (2015), konstatując, że przebieg jordańskiego procesu demokratyzacji może być w pełni zrozumiany jedynie przy jednoczesnym zestawieniu wielowymiarowych czynników o częstokroć odmiennym charakterze i sile oddziaływania. Co więcej, jak zauważył Hinnebusch (2010), demokratyzacja jest tylko jedną z możliwych opcji, jaką decydenci polityczni mogą obrać w szerszym procesie państwotwórczym, w odpowiedzi na wyzwania docierające do ośrodka władzy tak ze strony społeczeństwa, jak i środowiska międzynarodowego. Zachodzi ona tylko wtedy, gdy odpowiedź ta przyczyni się do wzrostu inkluzyjności oraz konkurencyjności procesów politycznych. Alternatywą jest stabilizacja reżimów autorytarnych i hybrydowych, powszechnie występująca w regionie bliskowschodnim.

Tak jak system międzynarodowy, MSH nie jest monolitem; w jej obrębie istnieją grupy autorów odwołujących się do różnych koncepcji teoretycznych. To zróżnicowanie poglądów w klarowny sposób ukazuje poniższy diagram (rysunek 2). 


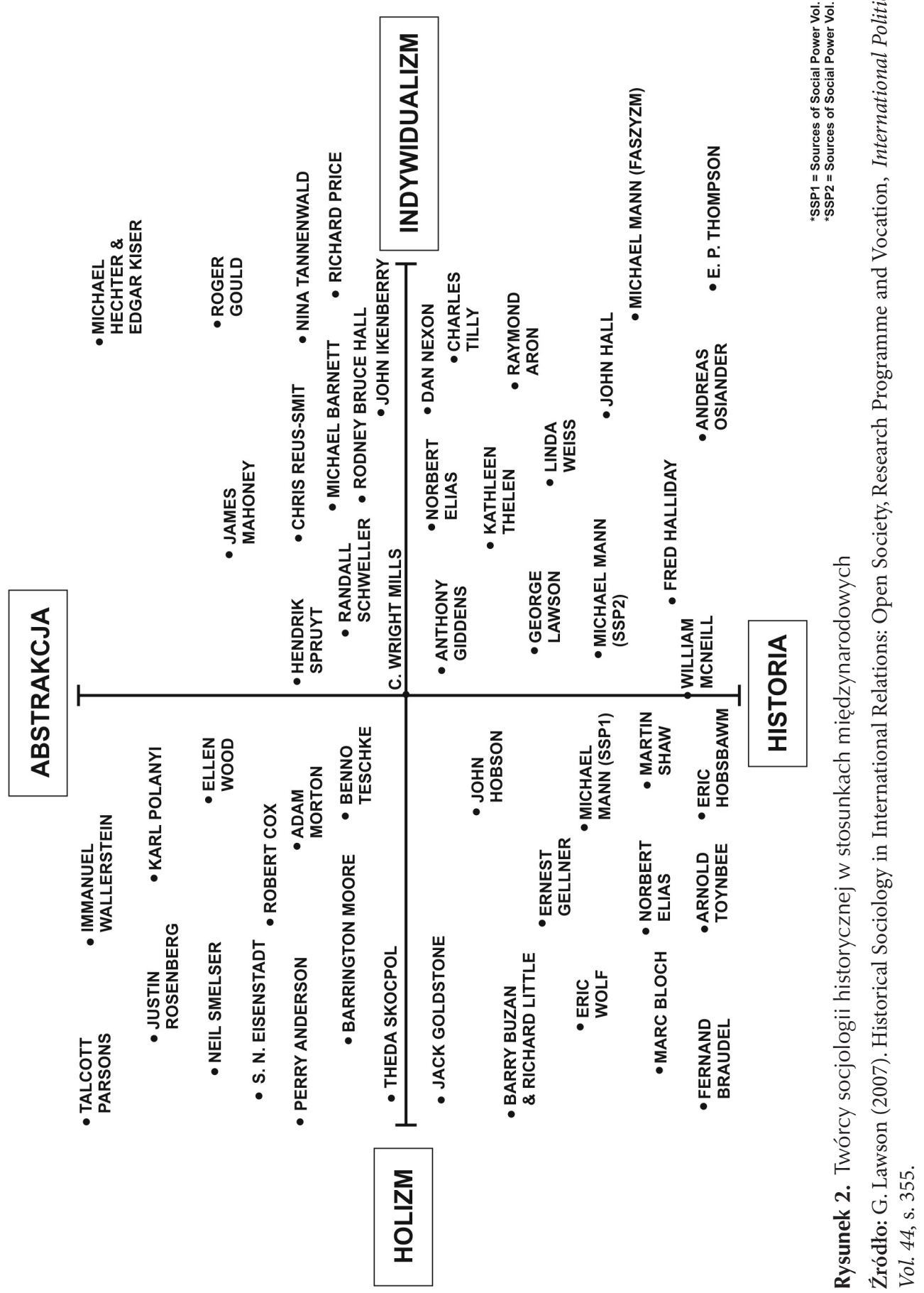


Dwie osie wyznaczające podział między zwolennikami holizmu i indywidualizmu oraz abstrakcji i historii dzielą socjologów historycznych na cztery grupy. Lewy górny róg zajmują (neo)marksiści ${ }^{6}$ oraz strukturalni funkcjonaliści, lewy dolny róg jest zaś zdominowany przez światowych historyków; w prawym dolnym rogu znajdują się przedstawiciele szkoły (neo)weberowskiej, a w prawym górnym rogu - zwolennicy teorii racjonalnego wyboru, analizy sieciowej i innych podejść metodologicznych (Lawson, 2007). Na przykładzie Michaela Manna widać jednak, że przynależność do określonej grupy nie musi być stała. Zdecydowana większość autorów przemawia jednak tym samym językiem: są oni zainteresowani wyjaśnianiem przyczynowym, badaniem międzynarodowych zmian, teoretyzowaniem państwa oraz rozwojem analizy stosunków międzynarodowych w oparciu o empirię i świadomość historyczną (Hobson, Hobden, 2002).

Aby tego dokonać, socjologia historyczna proponuje następujące rozwiązania: 1) przywiązanie do ontologicznie złożonych modeli przyczynowości, a tym samym odrzucenie reguły parsymonii; 2) przywiązanie do „neointegracjonizmu”, który odrzuca oddzielne traktowanie porządku wewnętrznego i międzynarodowości; 3) przywiązanie do „strukturacjonizmu” (structurationism), gdzie ani struktury, ani agenci nie są podmiotami prymitywnymi, w związku z czym analizowane są procesy ich wzajemnego konstytuowania (Hobson, Hobden, 2002) ${ }^{7}$. Służyć temu mają dwa narzędzia: realizm ontologiczny oraz relacjonizm epistemologiczny. Socjologia historyczna uznaje bowiem istnienie podstawowej rzeczywistości społecznej, ale też rozumie, że wszystkie relacje społeczne istnieją we współzależności z innymi. Stąd też potrzebne jest wskazanie ich różnic, wielości i interakcji, ponieważ MSH zasadza się na badaniu związków, relacji i procesów konstytuujących świat społeczny, a nie na analizie uprzedmiotowionych i statycznych faktów społecznych (Lawson, 2007).

6 W nurt neomarksizmu wpisują się prace aplikujące zyskującą na popularności koncepcję nierównego i połączonego rozwoju (uneven and combined development), którą na grunt nauki o stosunkach międzynarodowych zaszczepił Justin Rosenberg. Zob. np. Rosenberg, 2006, 2010; Callinicos, Rosenberg, 2008; Allinson, Anievas, 2009.

7 Giddens (1979) stwierdza, że agencja i struktura są wzajemnie powiązane, tj. struktury społeczne są zarówno wytworem ludzkiej agencji, jak i jednym z czynników je kształtujących. Innymi słowy, ludzie tworzą społeczeństwa, ale czynią to jako historycznie umiejscowieni aktorzy, w warunkach, które często nie są od nich zależne. Podobne powiązania można przenieść na poziom państwo-system międzynarodowy. Stanowisko Giddensa wyraźnie nawiązuje do twórczości Karola Marksa. Zob. Marx, 1978. 
Co niezwykle ważne, socjologia historyczna ma wymiar bardzo praktyczny jest podejściem stosowanym. Połączenie historii (zapis mówiący, dlaczego, kiedy i jak się coś wydarzyło) oraz socjologii (wyjaśnienie znaczenia poszczególnych wydarzeń) pozwala udzielić odpowiedzi na kolejne pytania: Co w związku z tym? Jakie wnioski można $\mathrm{z}$ tego wysnuć na przyszłość? Jakie są możliwe następstwa (Lawson, 2006)? W odniesieniu do sfery stosunków międzynarodowych daje to szerokie pole do analiz i interpretacji.

\section{KONKLUZJE}

Nauka o stosunkach międzynarodowych ma charakter interdyscyplinarny i nie może istnieć w oderwaniu od historii, socjologii, ekonomii, filozofii, prawa i innych dziedzin nauki. Jak zauważył Kukułka (2000, s. 149), ,interdyscyplinarność wymaga wykorzystania metod i technik badawczych innych dyscyplin w tym zakresie, w jakim podejmują one badanie stosunków międzynarodowych", a w efekcie kompleksowe i dynamiczne podejście do przedmiotu analizy. Krokiem w kierunku rozwiązania tego problemu jest stosunkowo nowe podejście badawcze w stosunkach międzynarodowych - międzynarodowa socjologia historyczna, którego podstawowym założeniem jest brak autonomii świata polityki i konieczność jego rozważania w powiązaniu z wieloma procesami społecznymi. Jak słusznie stwierdza Lawson (2005, s. 16), „,kombinacja historii i socjologii jest niezbędna do każdych badań, które chcą wyjaśnić dynamikę relacji między szczegółem a ogółem, jednostką a zbiorowością, agencją a strukturą". Warto zaznaczyć, że socjologia historyczna wykształciła się głównie w odpowiedzi na zarzuty, jakie stawiano wobec neorealizmu: brak teorii państwa, dychotomię „zewnętrzności” i „wewnętrzności”, brak teorii międzynarodowej zmiany, statyczność oraz ahistorycyzm (Hobson, 2000).

MSH w sposób jednoznaczny stwierdza, że wymiary wewnętrzny i międzynarodowy są ze sobą ściśle powiązane, a co za tym idzie - należy je analizować wspólnie. Jednocześnie zachodzą bowiem procesy, które Maj (2013) nazywa internacjonalizacją problemów wewnątrzpaństwowych oraz internalizacją problemów globalnych. Ponadto podkreśla się rolę historii nie tylko jako źródła indukcji, ale również jako sposobu myślenia o rozwoju międzynarodowych procesów i instytucji oraz zmiany społecznej. Uproszczony schemat zależności i powiązań w stosunkach międzynarodowych według socjologii historycznej prezentuje rysunek 3. Zdaniem autora jest to szablon bardzo trafnie określający 
sytuację społeczno-polityczną w wielu kontekstach pozaeuropejskich, a w szczególności w regionie Bliskiego Wschodu, w związku z czym jest on wart szczegółowych badań i analiz.

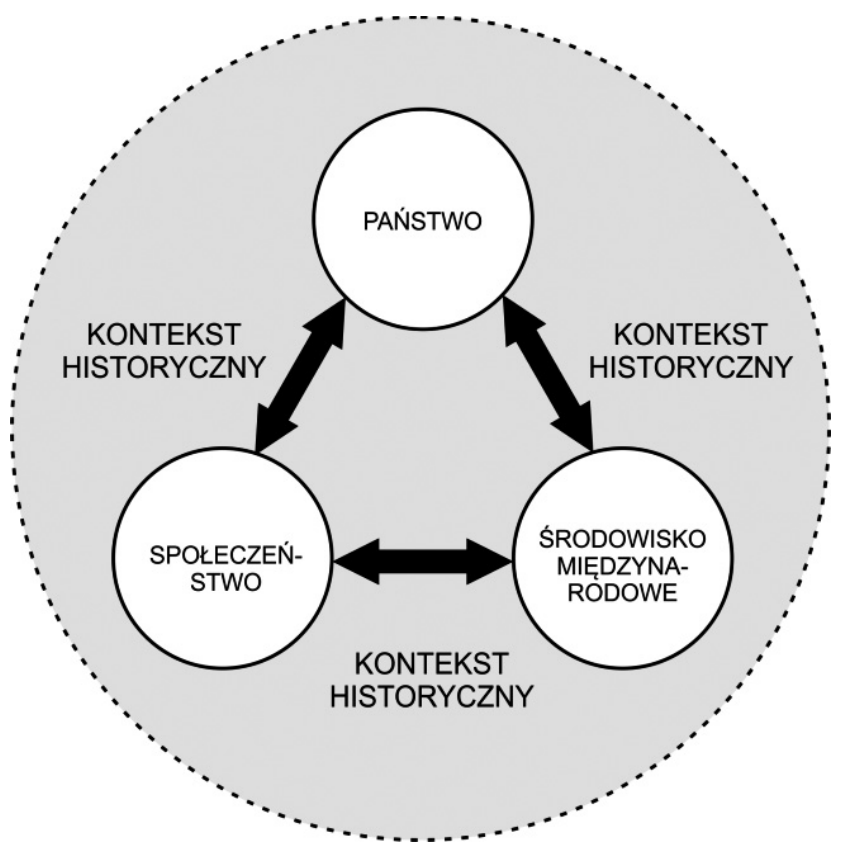

Rysunek 3. Stosunki międzynarodowe według międzynarodowej socjologii historycznej

Źródło: Opracowanie własne.

BIBLIOGRAFIA:

Allinson, J. (2015). The Struggle for the State in Jordan: The Social Origins of Alliances in the Middle East. London: I.B. Tauris.

Allinson, J., Anievas, A. (2009). The uses and misuses of uneven and combined development: an anatomy of a concept. Cambridge Review of International Affairs, 22/1, $47-66$.

Aron, R. (1986). History, Truth and Liberty: Selected Writings. Chicago: University of Chicago Press.

Barnett, M. (2002). Historical sociology and constructivism: an estranged past, a federated future? W: S. Hobden, J. Hobson (red.), Historical Sociology of International Relations (s. 99-119). Cambridge: Cambridge University Press.

Bromley, S. (1994). Rethinking Middle East Politics. Austin: University of Texas Press. 
Bryant, J.M. (1994). Evidence and explanation in history and sociology. British Journal of Sociology, 45/1, 3-19.

Callinicos, A., Rosenberg, J. (2008). Uneven and combined development: the social-relational substratum of the 'international'? An exchange of letters. Cambridge Review of International Affairs, 21/1,77-112.

Chatterjee, A. (2012). Theorizing the Global South in IR: Problems and Prospects, Paper presented at the $1^{\text {st }}$ Global South International Studies Conference, Menton.

Czaputowicz, J. (2008). Teorie stosunków międzynarodowych. Krytyka i systematyzacja. Warszawa: Wyd. Naukowe PWN.

Gałganek, A. (2007). Czy istnieje teoria społeczna „międzynarodowości” i „wewnętrzności”? Przegląd Politologiczny, XII/2, 21-38.

Gałganek, A. (2009). Abstrakcja nierównego i połączonego rozwoju w wyjaśnianiu historii stosunków międzynarodowych, Prawo i Polityka, 1/1,53-84.

Gałganek, A. (2010). Genealogia międzynarodowości. Społeczna teoria stosunków międzynarodowych. Przeglad Politologiczny, XV/3, 7-22.

Gałganek, A. (2012). Międzynarodowa socjologia historyczna i socjologia międzynarodowości. W: A. Gałganek, E. Haliżak, M. Pietraś (red.), Wielo- i interdyscyplinarność nauki o stosunkach międzynarodowych (s. 77-102). Warszawa: Wydawnictwo Rambler.

Gałganek, A. (2013a). Historia stosunków międzynarodowych: nierówny i połączony rozwój. T. 1, Idee. Warszawa: Dom Wydawniczy Elipsa.

Gałganek, A. (2013b). Historia stosunków międzynarodowych: nierówny i połaczony rozwój. T. 2, Rzeczy i praktyki. Warszawa: Dom Wydawniczy Elipsa.

Giddens, A. (1979). Central Problems in Social Theory. Action, structure and contradiction in social analysis. London: Macmillan Press.

Giddens, A. (1985). The Nation-State and Violence. Cambridge: Polity.

Grugel, J. (2002). Democratization: a critical introduction. New York: Palgrave Macmillan.

Halliday, F. (1994). Rethinking International Relations. London: Macmillan.

Halliday, F. (2002). For an international sociology. W: S. Hobden, J. Hobson (red.), Historical Sociology of International Relations (s. 99-119). Cambridge: Cambridge University Press.

Halliday, F. (2009). Bliski Wschód w stosunkach międzynarodowych. Władza, polityka i ideologia. Kraków: Wyd. Uniwersytetu Jagiellońskiego.

Halperin, S. (1998). Shadowboxing: Weberian historical sociology vs state-centric international relations theory. Review of International Political Economy, 5/2, 327-339.

Halperin, S. (2005). The Post-Cold War Political Topography of the Middle East: prospects for democracy. Third World Quarterly, 26, 1135-1136.

Hinnebusch, R. (2006). Authoritarian Persistence, Democratization Theory and the Middle East: An Overview and Critique. Democratization, 13/3, 373-395.

Hinnebusch, R. (2010). Toward a Historical Sociology of State Formation in the Middle East. Middle East Critique, 19/3, 201-216. 
Hinnebusch, R. (2014a). Historical Sociology and the Arab Uprisings. Mediterranean Politics, 19/1, 137-140.

Hinnebusch, R. (2014b). A Historical Sociology Approach to Authoritarian Resilience in Post-Arab Uprising MENA. POMEPS Memo. Pobrane z: http://pomeps.org/ 2014/12/19/a-historical-sociology-approach-to-authoritarian-resilience.

Hobden, S. (1998). International Relations and Historical Sociology: Breaking Down Boundaries. Florence: Routledge.

Hobden, S. (2002). Historical sociology: back to the future of international relations? W: S. Hobden, J. Hobson (red.), Historical Sociology of International Relations (s. 42-59). Cambridge: Cambridge University Press.

Hobson, J. (1998). The historical sociology of the state and the state of historical sociology in international relations. Review of International Political Economy, 5/2, $284-320$.

Hobson, J. (2000). State and International Relations. Cambridge: Cambridge University Press.

Hobson, J. (2002a). The two waves of Weberian historical sociology in international relations. W: S. Hobden, J. Hobson (red.), Historical Sociology of International Relations (s. 63-81). Cambridge: Cambridge University Press.

Hobson, J. (2002b). What's at stake in 'bringing historical sociology back into international relations'? Transcending 'chronofetishism' and 'tempocentrism' in international relations. W: S. Hobden, J. Hobson (red.), Historical Sociology of International Relations (s. 3-41). Cambridge: Cambridge University Press.

Hobson, J., Hobden, S. (2002). On the road towards an historicized world sociology. W: S. Hobden, J. Hobson (red.), Historical Sociology of International Relations (s. 265-285). Cambridge: Cambridge University Press.

Hobson, J., Lawson, G., Rosenberg, J. (2010). Historical Sociology. Pobrane z: http:// eprints.lse.ac.uk/28016/.

Kolasa-Nowak, A. (1996). Socjologia historyczna - problemy przedsięwzięcia interdyscyplinarnego. Historyka, t. XXVI, 3-20.

Kolasa-Nowak, A. (2001). Socjolog w badaniu przeszłości. Koncepcja socjologii historycznej Charlesa Tilly'ego. Lublin: Wyd. UMCS.

Kukułka, J. (1978). Problemy teorii stosunków międzynarodowych. Warszawa: Państwowe Wydawnictwo Naukowe.

Kukułka, J. (2002). Teoria stosunków międzynarodowych. Warszawa: Wydawnictwo Naukowe Scholar.

Lapointe, T., Dufour, F.G. (2012). Assessing the historical turn in IR: an anatomy of second wave historical sociology. Cambridge Review of International Affairs, 1/25, 97-121.

Lawson, G. (2005). Negotiated Revolutions: The Czech Republic, South Africa and Chile. Aldershot: Ashgate.

Lawson, G. (2006). The Promise of Historical Sociology in International Relations. International Studies Review, 8, 397-423. 
Lawson, G. (2007). Historical Sociology in International Relations: Open Society, Research Programme and Vocation. International Politics, 44, 343-368.

Linklater, A. (2013). Historical Sociology. W: S. Burchill, A. Linklater (red.), Theories of International Relations (s. 138-160). New York: Palgrave Macmillan.

Mahoney, J. (2000). Path dependence in historical sociology. Theory and Society, 29, 507-548.

Maj, Cz. (2013). Socjologia stosunków międzynarodowych. Lublin: Wydawnictwo Uniwersytetu Marii Curie-Skłodowskiej.

Malantowicz, A. (2015). Uwarunkowania procesu demokratyzacji Jordańskiego Królestwa Haszymidzkiego w latach 1989-2013, niepublikowana rozprawa doktorska, Uniwersytet Warszawski.

Mann, M. (1986). The Sources of Social Power Vol. 1. Cambridge: Cambridge University Press.

Marx, K. (1978). The Eighteenth Brumaire of Louis Bonaparte. W: R.C. Tucker (red.), The Marx-Engels Reader (s. 549-617). New York: Norton.

Matin, K. (2007). Uneven and Combined Development in World History: The International Relations of State-formation in Premodern Iran. European Journal of International Relations, 13/3, 419-447.

Paleczny, T. (2001). Socjologia stosunków międzynarodowych: zarys problematyki. Kraków: Krakowskie Towarzystwo Edukacyjne.

Putnam, R.D. (1993). Diplomacy and Domestic Politics: The Logic of Two-Level Games. W: P.B. Evans, H.K. Jacobsen, R.D. Putnam (red.), Double-Edged Diplomacy: International Bargaining and Domestic Politics (s. 431-468). Berkeley: University of California Press.

Reus-Smit, Ch. (2002). The idea of history and history with ideas. W: S. Hobden, J. Hobson (red.), Historical Sociology of International Relations (s. 120-140). Cambridge: Cambridge University Press.

Rosenberg, J. (2006). Why is There No International Historical Sociology? European Journal of International Relations, 12/3, 307-340.

Rosenberg, J. (2010). Basic problems in the theory of uneven and combined development. Part II: unevenness and political multiplicity. Cambridge Review of International Affairs, 23/1, 165-189.

Skocpol, Th. (1979). States and Social Revolutions. A Comparative Analysis of France, Russia and China. Cambridge: Cambridge University Press.

Skocpol, Th. (red.). (1984). Vision and Method in Historical Sociology. Cambridge/New York: Cambridge University Press.

Smith, D. (1991). The Rise of Historical Sociology. Cambridge: Polity Press.

Smith, S. (2002). Historical sociology and international relations theory. W: S. Hobden, J. Hobson (red.), Historical Sociology of International Relations (s. 223-243). Cambridge: Cambridge University Press.

Tell, T. (2013). The Social and Economic Origins of Monarchy in Jordan. New York: Palgrave Macmillan. 
Teschke, B. (2011). Advances and impasses in Fred Halliday's international historical sociology: a critical appraisal. International Affairs, 87, 1087-1106.

Tilly, Ch. (1990). Coercion, Capital and European States AD 990-1990. Oxford: Blackwell.

Wiatr J.J. (1969). Socjologiczne ujęcie stosunków międzynarodowych. Studia Nauk Politycznych, 3, 55-70. 